\title{
The Homocoupling Reaction of Aromatic Terminal Alkynes by a Highly Active Palladium(II)/AgNO 3 Cocatalyst in Aqueous Media Under Aerobic Conditions
}

\author{
Mengping Guo ${ }^{1,2, *}$, Bo Chen ${ }^{1,2}$, Meiyun Lv ${ }^{1}$, Xiuling Zhou ${ }^{1}$, Yongju Wen ${ }^{1}$ and Xiuli Shen ${ }^{1}$ \\ 1 Institue of Coordination Catalysis, College of Chemistry and Bio-Engineering, Yichun University, \\ Yichun 336000, China; chenbo25719@163.com (B.C.); lvmeiyun2005@163.com (M.L.); \\ 13879593114@163.com (X.Z.); wenyongjujuju@163.com (Y.W.); shenxiuliwyj@163.com (X.S.) \\ 2 Engineering Center of Jiangxi University for Lithium Energy, Yichun University, Yichun 336000, China \\ * Correspondence: guomengping65@163.com; Tel./Fax: +86-79-5320-0535
}

Academic Editors: Diego A. Alonso and Isidro M. Pastor

Received: 12 April 2016; Accepted: 3 May 2016; Published: 10 May 2016

\begin{abstract}
A new and efficient $\mathrm{Pd}$ (II)/ $\mathrm{AgNO}_{3}$-cocatalyzed homocoupling of aromatic terminal alkynes is described. Various symmetrical 1,4-disubstituted-1,3-diynes are obtained in good to excellent yields. This protocol employs a loading with relatively low palladium(II) in aqueous media under aerobic conditions.
\end{abstract}

Keywords: aromatic terminal alkynes; palladium(II) $/ \mathrm{AgNO}_{3}$ cocatalyzing; homocoupling reaction

\section{Introduction}

Compounds which contain a 1,4-disubstituted-1,3-diyne linkage have been found in applications in areas ranging from pharmaceuticals with anti-inflammatory, antibacterial, antitumor, and antifungal activities to a large variety of polymers, biologically active molecules, and supramolecular materials with appreciable photoelectrical properties [1-6]. The homocoupling reaction of terminal alkyne is the classical protocol, and the choice of the catalytic system is a pivotal factor for the synthesis of symmetrical 1,3-diynes [7-10]. Palladium complexes in combination with $\mathrm{Cu}$ salts are traditionally employed as cocatalysts for the reaction [11-18]. Recently, apart from copper salts, catalysts, based on other transition metals such as $\mathrm{Ni}$ [19], $\mathrm{Co}$ [20], $\mathrm{Au}$ [21], and $\mathrm{Ti}$ [22] have also been employed in terminal alkyne homocoupling reactions. Moreover, an iron in combination with a $\mathrm{Cu}$ salt cocatalyst has also been reported [23]. Furthermore, the metal-free cocatalyst palladium-catalyzed homocoupling reactions have been described [24,25]. However, to the best of our knowledge, $\mathrm{Ag}_{2} \mathrm{O}$ has been reported as a cocatalyst for the homocoupling reaction of terminal alkynes [26], but $\mathrm{Ag}(\mathrm{I})$ as a cocatalyst has not been reported. Our group has recently synthesized and characterized a new palladium(II) complex (1) (Figure 1) via single-crystal X-ray crystallography. Owing to the inertness of the palladium(II) complex (1) towards oxygen and moisture, it has been used as catalyst in an aerobic Suzuki coupling reaction [27] and an aerobic cyanation of aryl halides [28]. Herein, we wish to report the use of a new $\mathrm{Pd}(\mathrm{II}) / \mathrm{AgNO}_{3}$ cocatalytic system for the homocoupling reaction of aromatic terminal alkyne under aerobic conditions. 


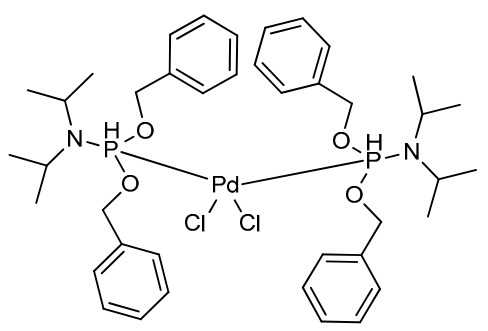

(1)

Figure 1. Palladium(II) complex (1).

\section{Results and Discussion}

\subsection{Optimization of the Homocoupling Reaction Conditions}

In our initial experiments, we observed that the homocoupling of phenylacetylene $(1 \mathrm{mmol}, \mathbf{1 a})$ in the presence of $\mathrm{Pd}$ (II) complex $1(0.5 \mathrm{~mol} \%)$ and $\mathrm{NaOH}(1 \mathrm{mmol})$ in THF/ $\mathrm{H}_{2} \mathrm{O}$ (in 4:1 proportion, $2.5 \mathrm{~mL}$ ) at $60{ }^{\circ} \mathrm{C}$ proceeded to give the desired homocoupling product (2a) in a small isolated yield $(<10 \%)$ (Table 1, Entry 1). After an addition of $\mathrm{AgNO}_{3}(0.05 \mathrm{mmol})$, the yield was up to $51 \%$ under the same conditions (Table 1, Entry 2). This observation prompted us to further investigate the effect of a base on this protocol, finding that the best result was obtained in the presence of $\mathrm{Cs}_{2} \mathrm{CO}_{3}$ as a base (Table 1, Entry 11). The effect of the solvent in the reaction was also studied using a different co-solvent, and a $93 \%$ yield of the desired product (2a) was isolated in $n$-butyl alcohol $/ \mathrm{H}_{2} \mathrm{O}$ (in 4:1 proportion, $2.5 \mathrm{~mL}$ ) (Table 1, Entry 22). Consequently, $n$-butyl alcohol $/ \mathrm{H}_{2} \mathrm{O}$ was chosen as the best co-solvent.

Table 1. Effects of solvent and base on the homocoupling of phenylacetylene ${ }^{\mathrm{a}}$.

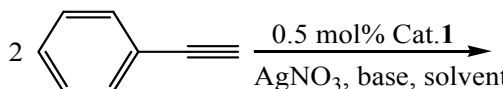

$1 \mathbf{a}$

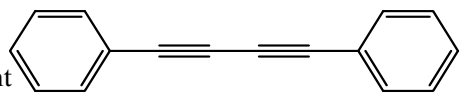

2a

\begin{tabular}{|c|c|c|c|}
\hline Entry & Ase & Solvent & Yield ${ }^{c}(\%)$ \\
\hline $1^{b}$ & $\mathrm{NaOH}$ & $\mathrm{THF} / \mathrm{H}_{2} \mathrm{O}$ & 10 \\
\hline 2 & $\mathrm{NaOH}$ & $\mathrm{THF} / \mathrm{H}_{2} \mathrm{O}$ & 51 \\
\hline 3 & $\mathrm{KOH}$ & $\mathrm{THF} / \mathrm{H}_{2} \mathrm{O}$ & 45 \\
\hline 4 & $\mathrm{Na}_{2} \mathrm{CO}_{3}$ & $\mathrm{THF} / \mathrm{H}_{2} \mathrm{O}$ & 67 \\
\hline 5 & $\mathrm{~K}_{2} \mathrm{CO}_{3}$ & $\mathrm{THF} / \mathrm{H}_{2} \mathrm{O}$ & 57 \\
\hline 6 & $\mathrm{NaHCO}_{3}$ & $\mathrm{THF} / \mathrm{H}_{2} \mathrm{O}$ & 63 \\
\hline 7 & $\mathrm{NaH}_{2} \mathrm{PO}_{4}$ & $\mathrm{THF} / \mathrm{H}_{2} \mathrm{O}$ & 71 \\
\hline 8 & $\mathrm{KHCO}_{3}$ & $\mathrm{THF} / \mathrm{H}_{2} \mathrm{O}$ & 64 \\
\hline 9 & $\mathrm{KH}_{2} \mathrm{PO}_{4}$ & $\mathrm{THF} / \mathrm{H}_{2} \mathrm{O}$ & 70 \\
\hline 10 & $\mathrm{~K}_{3} \mathrm{PO}_{4}$ & $\mathrm{THF} / \mathrm{H}_{2} \mathrm{O}$ & 70 \\
\hline 11 & $\mathrm{Cs}_{2} \mathrm{CO}_{3}$ & $\mathrm{THF} / \mathrm{H}_{2} \mathrm{O}$ & 85 \\
\hline 12 & $\mathrm{NaF}$ & $\mathrm{THF} / \mathrm{H}_{2} \mathrm{O}$ & 47 \\
\hline 13 & $\mathrm{CH} 3 \mathrm{COONa}$ & $\mathrm{THF} / \mathrm{H}_{2} \mathrm{O}$ & 53 \\
\hline 14 & $\mathrm{NEt}_{3}$ & $\mathrm{THF} / \mathrm{H}_{2} \mathrm{O}$ & 63 \\
\hline 15 & Pyridine & $\mathrm{THF} / \mathrm{H}_{2} \mathrm{O}$ & 54 \\
\hline 16 & $\mathrm{Cs}_{2} \mathrm{CO}_{3}$ & $\mathrm{DMSO} / \mathrm{H}_{2} \mathrm{O}$ & 47 \\
\hline 17 & $\mathrm{Cs}_{2} \mathrm{CO}_{3}$ & $\mathrm{~N}, \mathrm{~N}$-Dimethylacetylamide $/ \mathrm{H}_{2} \mathrm{O}$ & O 39 \\
\hline 18 & $\mathrm{Cs}_{2} \mathrm{CO}_{3}$ & $\mathrm{PEG} 400 / \mathrm{H}_{2} \mathrm{O}$ & 59 \\
\hline 19 & $\mathrm{Cs}_{2} \mathrm{CO}_{3}$ & Acetone $/ \mathrm{H}_{2} \mathrm{O}$ & 88 \\
\hline 20 & $\mathrm{Cs}_{2} \mathrm{CO}_{3}$ & 1,4-Dioxane $/ \mathrm{H}_{2} \mathrm{O}$ & 79 \\
\hline 21 & $\mathrm{Cs}_{2} \mathrm{CO}_{3}$ & Ethanol $/ \mathrm{H}_{2} \mathrm{O}$ & 54 \\
\hline 22 & $\mathrm{Cs}_{2} \mathrm{CO}_{3}$ & $N$-Butyl alcohol $/ \mathrm{H}_{2} \mathrm{O}$ & 93 \\
\hline 23 & $\mathrm{Cs}_{2} \mathrm{CO}_{3}$ & Methanol $/ \mathrm{H}_{2} \mathrm{O}$ & 45 \\
\hline
\end{tabular}

a The reaction was performed with phenylacetylene $(1 \mathrm{mmol}), \mathrm{Pd}(\mathrm{II})$ complex catalyst 1 (0.5 mol \%), $\mathrm{AgNO}_{3}(0.05 \mathrm{mmol})$, and base $(1 \mathrm{mmol})$ in solvent $/ \mathrm{H}_{2} \mathrm{O}(2.5 \mathrm{~mL}, v / v=4: 1)$ at $60^{\circ} \mathrm{C}$ under aerobic conditions for $24 \mathrm{~h} .{ }^{\mathrm{b}}$ In the absence of $\mathrm{AgNO}_{3} .{ }^{\mathrm{c}}$ Isolated yield. 
We continued to examine the influence of the ratio of co-solvent, temperature, time, and amount of catalyst and $\mathrm{AgNO}_{3}$ on the yields. As can be seen in Table 2, the reaction proceeded perfectly to obtain $97 \%$ yield in $n$-butyl alcohol $/ \mathrm{H}_{2} \mathrm{O}$ (in 1:2 proportion, $3 \mathrm{~mL}$ ) in the presence of $1(0.5 \mathrm{~mol} \%)$ and $\mathrm{AgNO}_{3}(0.05 \mathrm{mmol})$ at $60{ }^{\circ} \mathrm{C}$ under aerobic conditions (Table 2, Entry 5), but only a trace yield of 1,4-diphenylbuta-1,3-diyne (2a) was obtained in the absence of $\mathrm{Pd}(\mathrm{II})$ complex catalyst $\mathbf{1}$ or $\mathrm{AgNO}_{3}$ (Table 2, Entries 7,11). However, when $0.5 \mathrm{~mol} \% \mathrm{Pd}(\mathrm{II})$ complex catalyst 1 and $0.075 \mathrm{~mol} \% \mathrm{AgNO}_{3}$ were used as a cocatalyst, the yield obviously enhanced, with the homocoupling of phenylacetylene (1a) being quantitative (Table 2, Entry 14). These results show that both $\mathrm{Pd}(\mathrm{II})$ complex catalyst 1 and $\mathrm{AgNO}_{3}$ play important roles in the oxidative homocoupling reaction of terminal alkynes. Then the temperature effects were examined in this homocoupling reaction, finding that the homocoupling product 2a was obtained in higher yield $(99 \%)$ at $60^{\circ} \mathrm{C}$, but in lower yield $(92 \%)$ at $80{ }^{\circ} \mathrm{C}$ (Table 2 , Entries 14,21), which is consistent with the results of Shi and colleagues [14]. With a lower temperature $\left(40{ }^{\circ} \mathrm{C}\right)$, 2a was obtained in moderate yield (56\%) (Table 2, Entry 20). Under these reaction conditions, prolonging the homocoupling reaction time from 4-24 h, the yield of $2 \mathrm{a}$ increased from $13 \%$ to $99 \%$ (Table 2, Entries 14,16-18). In a word, the best result was obtained to carry out the reaction in $n$-butyl alcohol $/ \mathrm{H}_{2} \mathrm{O}$ (in 1:2 proportion) using $\mathrm{Cs}_{2} \mathrm{CO}_{3}$ as a base at $60^{\circ} \mathrm{C}$ under aerobic conditions for $24 \mathrm{~h}$.

Table 2. Effects of other reaction conditions on the homocoupling of phenylacetylene ${ }^{\mathrm{a}}$.

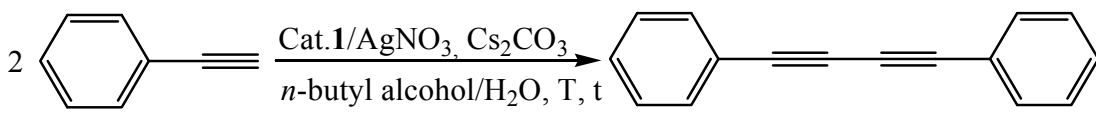

$1 \mathbf{a}$

$\mathbf{2 a}$

\begin{tabular}{|c|c|c|c|c|c|c|}
\hline Entry & $\begin{array}{c}n \text {-Butyl } \\
\text { alcohol/ } \mathrm{H}_{2} \mathrm{O}(v / v)\end{array}$ & $\begin{array}{l}\text { Catalyst } \\
(\mathrm{mol} \%)\end{array}$ & $\begin{array}{l}\mathrm{AgNO}_{3} \\
\text { (mmol) }\end{array}$ & $\begin{array}{l}\text { Time } \\
\text { (h) }\end{array}$ & $\begin{array}{c}\text { Temperature } \\
\left({ }^{\circ} \mathrm{C}\right)\end{array}$ & $\begin{array}{c}\text { Yield }^{b} \\
(\%)\end{array}$ \\
\hline 1 & $3: 0$ & 0.5 & 0.05 & 24 & 60 & 50 \\
\hline 2 & $2: 0.5$ & 0.5 & 0.05 & 24 & 60 & 89 \\
\hline 3 & $2: 1$ & 0.5 & 0.05 & 24 & 60 & 89 \\
\hline 4 & $1.5: 1.5$ & 0.5 & 0.05 & 24 & 60 & 93 \\
\hline 5 & $1: 2$ & 0.5 & 0.05 & 24 & 60 & 97 \\
\hline 6 & $0: 3$ & 0.5 & 0.05 & 24 & 60 & 48 \\
\hline 7 & $1: 2$ & 0 & 0.05 & 24 & 60 & trace \\
\hline 8 & $1: 2$ & 0.25 & 0.05 & 24 & 60 & 65 \\
\hline 9 & $1: 2$ & 1 & 0.05 & 24 & 60 & 96 \\
\hline 10 & $1: 2$ & 1.5 & 0.05 & 24 & 60 & 90 \\
\hline 11 & $1: 2$ & 0.5 & 0 & 24 & 60 & trace \\
\hline 12 & $1: 2$ & 0.5 & 0.01 & 24 & 60 & 35 \\
\hline 13 & $1: 2$ & 0.5 & 0.025 & 24 & 60 & 62 \\
\hline 14 & $1: 2$ & 0.5 & 0.075 & 24 & 60 & 99 \\
\hline 15 & $1: 2$ & 0.5 & 0.1 & 24 & 60 & 86 \\
\hline 16 & $1: 2$ & 0.5 & 0.075 & 4 & 60 & 13 \\
\hline 17 & $1: 2$ & 0.5 & 0.075 & 12 & 60 & 72 \\
\hline 18 & $1: 2$ & 0.5 & 0.075 & 21 & 60 & 76 \\
\hline 19 & $1: 2$ & 0.5 & 0.075 & 30 & 60 & 86 \\
\hline 20 & $1: 2$ & 0.5 & 0.075 & 24 & 40 & 56 \\
\hline 21 & $1: 2$ & 0.5 & 0.075 & 24 & 80 & 92 \\
\hline
\end{tabular}

a The reaction was performed with phenylacetylene $(1 \mathrm{mmol})$ and $\mathrm{Cs}_{2} \mathrm{CO}_{3}(1 \mathrm{mmol})$ under aerobic conditions;

b Isolated yield.

\subsection{Scope and Limitations of Substrates}

Encouraged by the efficiency of the reaction protocol described above, we investigated the substrate scope. A variety of aromatic terminal alkynes were tested to afford the corresponding aromatic 1,4-disubstituted-1,3-diyne derivatives in good to excellent yields under the optimized conditions. The results are summarized in Table 3. As can be seen, the homocoupling reactions of 
various aromatic acetylenes with electron-donating groups on aromatic rings such as methyl, $n$-butyl, tert-butyl, and methoxy gave almost the same high yields (82\%-93\%) (Table 3, Entries 2-7). Besides, no significant difference was observed in yield at the same reaction conditions when the effect of different position of the substituent groups on aromatic rings on the homocoupling reaction of aromatic terminal alkynes was studied (Table 3, Entries 2,3,6,7). However, the homocoupling product was obtained in lower yield $(56 \%)$ when aromatic acetylene with the electron-withdrawing fluoro group on the aromatic ring was homocoupled under optimized conditions (Table 3, Entry 8).

Table 3. $\mathrm{Pd}(\mathrm{II}) / \mathrm{AgNO}_{3}$-catalyzed the homocoupling reactions of aromatic terminal alkynes ${ }^{\mathrm{a}}$.

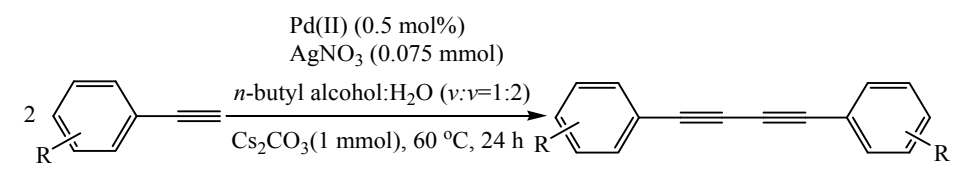

Entry

${ }^{a}$ Carried out with aromatic terminal alkyne $(1 \mathrm{mmol}), \mathrm{Pd}(\mathrm{II})$ complex catalyst $1(0.5 \mathrm{~mol} \%), \mathrm{AgNO}_{3}$ $(0.075 \mathrm{mmol})$, and $\mathrm{Cs}_{2} \mathrm{CO}_{3}(1 \mathrm{mmol})$ in $n$-butyl alcohol $/ \mathrm{H}_{2} \mathrm{O}$ (in $1: 2$ proportion, $3 \mathrm{~mL}$ ) at $60{ }^{\circ} \mathrm{C}$ under aerobic conditions for $24 \mathrm{~h}$; ${ }^{\mathrm{b}}$ Isolated yield.

\section{Experimental Section}

\subsection{Reagents and Machine}

The $\mathrm{Pd}(\mathrm{II})$ complex catalyst 1 was prepared according to a procedure found in the literature [27]. Aromatic alkyne derivatives were obtained commercially from J\&K Chemical Technology (Shanghai, China). All reagents employed in the reaction were analytical grade, and other chemicals were obtained 
commercially and used without any prior purification. All products were isolated using thin-layer chromatography (Qingdao Haiyang Chemical CO., Ltd, Qingdao, China) with GF254 silica gel using Petroleum ether and ethyl acetate unless otherwise noted. Products described in the literature were characterized using ${ }^{1} \mathrm{H}-\mathrm{NMR}$ and ${ }^{13} \mathrm{C}-\mathrm{NMR}$ spectra and compared with previously reported data. ${ }^{1} \mathrm{H}-\mathrm{NMR}$ and ${ }^{13} \mathrm{C}-\mathrm{NMR}$ spectra were recorded with a Bruker Avance II 400 spectrometer (Fällanden, Switzerland) using tetramethylsilane as the internal standard and $\mathrm{CDCl}_{3}$ as the solvent.

\subsection{General Experimental Procedure for the Homocoupling Reaction of Various Aromatic Alkynes}

All reactions were carried out under aerobic conditions. A mixture of aromatic alkyne $(1.0 \mathrm{mmol})$, $\mathrm{AgNO}_{3}(0.075 \mathrm{mmol}), \mathrm{Cs}_{2} \mathrm{CO}_{3}(1.0 \mathrm{mmol})$, catalyst compound $\mathbf{1}(0.5 \mathrm{~mol} \%)$, and $n$-butyl alcohol $/ \mathrm{H}_{2} \mathrm{O}$ (in 1:2 proportion, $3 \mathrm{~mL}$ ) was stirred at $60^{\circ} \mathrm{C}$ for $24 \mathrm{~h}$ and then extracted three times with ethyl acetate $(3 \times 15 \mathrm{~mL})$. The combined organic phase was dried with $\mathrm{MgSO}_{4}$, filtrated, and then solvent was removed on a rotary evaporator. The product was isolated by thin-layer chromatography. The purified products were identified by ${ }^{1} \mathrm{H}-\mathrm{NMR}$ and ${ }^{13} \mathrm{C}-\mathrm{NMR}$ spectroscopy (Figures S1-S10).

\subsection{Analytical Data of Representative Products}

1,4-Diphenylbuta-1,3-diyne (Table 3, Entry 1): White solid (m.p. $=86-87^{\circ} \mathrm{C}$, lit [29] 85-86 ${ }^{\circ} \mathrm{C}$ ). ${ }^{1} \mathrm{H}-\mathrm{NMR}$ $\left(400 \mathrm{MHz}, \mathrm{CDCl}_{3}\right): \delta 7.75-7.60(\mathrm{~m}, 4 \mathrm{H}), 7.60-7.40(\mathrm{~m}, 6 \mathrm{H}) .{ }^{13} \mathrm{C}-\mathrm{NMR}\left(101 \mathrm{MHz}, \mathrm{CDCl}_{3}\right): \delta 138.17$, $134.90,134.13,127.43,87.29,79.68$.

1,4-Di-o-tolybuta-1,3-diyne (Table 3, Entry 2): White solid (m.p. $=72-74{ }^{\circ} \mathrm{C}$, lit [30] 72-74 ${ }^{\circ} \mathrm{C}$ ). ${ }^{1} \mathrm{H}-\mathrm{NMR}$ $\left(400 \mathrm{MHz}, \mathrm{CDCl}_{3}\right): \delta 8.41(\mathrm{~d}, J=7.6 \mathrm{~Hz}, 2 \mathrm{H}), 8.19-8.09(\mathrm{~m}, 4 \mathrm{H}), 8.05(\mathrm{t}, J=7.4 \mathrm{~Hz}, 2 \mathrm{H}), 3.40(\mathrm{~s}, 6 \mathrm{H})$. ${ }^{13} \mathrm{C}-\mathrm{NMR}\left(101 \mathrm{MHz}, \mathrm{CDCl}_{3}\right): \delta$ 146.23, 137.53, 134.20, 133.74, 130.29, 126.33, 85.81, 82.22, 25.35.

1,4-Di-m-tolybuta-1,3-diyne (Table 3, Entry 3): White solid (m.p. $=69-71{ }^{\circ} \mathrm{C}$, lit [30] 68-70 ${ }^{\circ} \mathrm{C}$ ). ${ }^{1} \mathrm{H}-\mathrm{NMR}$ $\left(400 \mathrm{MHz}, \mathrm{CDCl}_{3}\right): \delta 8.40(\mathrm{~d}, J=6.4 \mathrm{~Hz}, 4 \mathrm{H}), 8.28(\mathrm{ddd}, J=22.5,9.9,4.4 \mathrm{~Hz}, 4 \mathrm{H}), 3.40(\mathrm{~s}, 6 \mathrm{H}) .{ }^{13} \mathrm{C}-\mathrm{NMR}$ $\left(101 \mathrm{MHz}, \mathrm{CDCl}_{3}\right):$ : $144.08,138.89,136.05,135.53,134.25,127.54,87.56,79.61,27.12$.

1,4-Bis(4-butylphenyl)buta-1,3-diyne (Table 3, Entry 4): White solid (m.p. $=65-66{ }^{\circ} \mathrm{C}$, lit [31] $67^{\circ} \mathrm{C}$ ). ${ }^{1} \mathrm{H}-\mathrm{NMR}\left(400 \mathrm{MHz}, \mathrm{CDCl}_{3}\right): \delta 8.12-7.99(\mathrm{~m}, 4 \mathrm{H}), 7.76(\mathrm{~d}, J=7.1 \mathrm{~Hz}, 4 \mathrm{H}), 3.22(\mathrm{t}, J=7.6 \mathrm{~Hz}, 4 \mathrm{H})$, 2.30-2.11 (m, 4H), $1.96(\mathrm{dd}, J=14.0,7.0 \mathrm{~Hz}, 4 \mathrm{H}), 1.55(\mathrm{t}, J=7.3,1.8 \mathrm{~Hz}, 6 \mathrm{H}) .{ }^{13} \mathrm{C}-\mathrm{NMR}(101 \mathrm{MHz}$, $\left.\mathrm{CDCl}_{3}\right): \delta 148.03,136.00,132.16,122.59,85.20,77.18,39.30,36.92,25.94,17.54$.

1,4-Bis(4-tert-butylphenyl)buta-1,3-diyne (Table 3, Entry 5): White solid (m.p. $=202-204{ }^{\circ} \mathrm{C}$, lit [32] 203-204 $\left.{ }^{\circ} \mathrm{C}\right) .{ }^{1} \mathrm{H}-\mathrm{NMR}\left(400 \mathrm{MHz}, \mathrm{CDCl}_{3}\right): \delta 7.88(\mathrm{~d}, J=7.4 \mathrm{~Hz}, 4 \mathrm{H}), 7.77(\mathrm{~d}, J=7.5 \mathrm{~Hz}, 4 \mathrm{H}), 1.73(\mathrm{~s}, 18 \mathrm{H})$. ${ }^{13} \mathrm{C}-\mathrm{NMR}\left(101 \mathrm{MHz}, \mathrm{CDCl}_{3}\right): \delta 156.51,136.24,129.45,122.80,85.49,77.50,38.86,35.08$.

1,4-Bis(4-methoxyphenyl)buta-1,3-diyne (Table 3, Entry 6): White solid (m.p. = 39-141 ${ }^{\circ} \mathrm{C}$, lit [29] $\left.138-139{ }^{\circ} \mathrm{C}\right) .{ }^{1} \mathrm{H}-\mathrm{NMR}\left(400 \mathrm{MHz}, \mathrm{CDCl}_{3}\right): \delta 8.17(\mathrm{~d}, J=8.6 \mathrm{~Hz}, 4 \mathrm{H}), 7.56(\mathrm{~d}, J=8.6 \mathrm{~Hz}, 4 \mathrm{H}), 4.51(\mathrm{~s}, 6 \mathrm{H})$. ${ }^{13} \mathrm{C}-\mathrm{NMR}\left(101 \mathrm{MHz}, \mathrm{CDCl}_{3}\right): \delta 164.19,137.99,136.34,133.18,118.09,117.85,85.51,85.21,76.92,59.27$.

1,4-Bis(2-methoxyphenyl)buta-1,3-diyne (Table 3, Entry 7): White solid(m.p. $=72-74{ }^{\circ} \mathrm{C}$, lit [13] 72-74 ${ }^{\circ} \mathrm{C}$ ). ${ }^{1} \mathrm{H}-\mathrm{NMR}\left(400 \mathrm{MHz}, \mathrm{CDCl}_{3}\right): \delta 7.73(\mathrm{dd}, J=7.6,1.3 \mathrm{~Hz}, 2 \mathrm{H}), 7.62-7.52(\mathrm{~m}, 2 \mathrm{H}), 7.15(\mathrm{dd}, J=16.6,8.1 \mathrm{~Hz}$, 4H), 4.14 (s, 6H). ${ }^{13} \mathrm{C}-\mathrm{NMR}: \delta 163.25,136.28,132.53,122.43,113.11,112.60,80.63,79.91,57.71$.

1,4-Bis(4-fluorophenyl)buta-1,3-diyne (Table 3, Entry 8): White solid (m.p. = 190-192 ${ }^{\circ} \mathrm{C}$, lit [29] 192-193 $\left.{ }^{\circ} \mathrm{C}\right) .{ }^{1} \mathrm{H}-\mathrm{NMR}\left(400 \mathrm{MHz}, \mathrm{CDCl}_{3}\right): \delta 8.09(\mathrm{dd}, J=8.6,5.4 \mathrm{~Hz}, 4 \mathrm{H}), 7.62(\mathrm{t}, J=8.6 \mathrm{~Hz}, 4 \mathrm{H})$. ${ }^{13} \mathrm{C}-\mathrm{NMR}\left(101 \mathrm{MHz}, \mathrm{CDCl}_{3}\right): \delta 137.11,118.60,118.38,83.00,76.09$.

1,4-Bis(3-chlorophenyl)buta-1,3-diyne (Table 3, Entry 9): White solid (m.p. $=73-74{ }^{\circ} \mathrm{C}$, lit [33] $73{ }^{\circ} \mathrm{C}$ ). ${ }^{1} \mathrm{H}-\mathrm{NMR}\left(400 \mathrm{MHz}, \mathrm{CDCl}_{3}\right): \delta 7.86(\mathrm{~s}, 2 \mathrm{H}), 7.74(\mathrm{dd}, J=19.5,8.0 \mathrm{~Hz}, 4 \mathrm{H}), 7.63(\mathrm{dd}, J=10.7,5.0 \mathrm{~Hz}, 2 \mathrm{H})$. ${ }^{13} \mathrm{C}-\mathrm{NMR}\left(101 \mathrm{MHz}, \mathrm{CDCl}_{3}\right): \delta$ 137.61, 135.52, 133.92, 132.98, 126.53, 83.82, 77.96. 
1,4-Bis(2-bromophenyl)buta-1,3-diyne (Table 3, Entry 10): White solid (m.p. = 180-182 ${ }^{\circ} \mathrm{C}$, lit [34] $182{ }^{\circ} \mathrm{C}$ ).

${ }^{1} \mathrm{H}-\mathrm{NMR}\left(400 \mathrm{MHz}, \mathrm{CDCl}_{3}\right): \delta 7.68-7.55(\mathrm{~m}, 4 \mathrm{H}), 7.38-7.20(\mathrm{~m}, 4 \mathrm{H}) .{ }^{13} \mathrm{C}-\mathrm{NMR}\left(101 \mathrm{MHz}, \mathrm{CDCl}_{3}\right)$ : $\delta 138.78,136.84,134.65,133.15,132.01,131.37,131.33,131.28,130.44,128.28,85.32,82.09$.

\section{Conclusions}

In summary, we have developed a new and efficient $\mathrm{Pd}(\mathrm{II}) / \mathrm{AgNO}_{3}$ catalytic system for the homocoupling of various terminal alkynes. It is noteworthy that our protocol employs a relatively low-palladium catalyst loading in aqueous media under aerobic conditions to obtain the coupled products in good to excellent yields. Currently, further efforts to study the mechanism and apply the new approach in other transformations are under way in our laboratory.

Supplementary Materials: Supplementary materials can be accessed at http://www.mdpi.com/1420-3049/21/ 5/606/s1.

Acknowledgments: This research was financially supported by the National Natural Science Foundation of China (No. 21363026), the Scientific and Technological Landing Project of Higher Education of Jiangxi Province (No. KJLD13091), and the Graduate Student' Innovative Education Program of Jiangxi Province (No. YC2014-S454).

Author Contributions: Mengping Guo and Bo Chen conceived and designed research. Meiyun Lv, Xiuling Zhou, Yongju Wen, and Xiuli Shen performed the experiments. Mengping Guo wrote the paper.

Conflicts of Interest: The authors declare no conflict of interest.

\section{References}

1. Glaser, C. Beitriige zur kenntnifs des acetenylbenzols. Ber. Dtsch. Chem. Ges. 1869, 2, 422-424. [CrossRef]

2. Shi Shun, A.L.K.S.; Tykwinski, R.R. Synthesis of naturally occurring polyynes. Angew. Chem. Int. Ed. 2006, 45, 1034-1057. [CrossRef] [PubMed]

3. Stefani, H.A.; Costa, I.M.; Zeni, G. Synthesis of polyacetylenic montiporic acids A and B. Terahedron Lett. 1999, 40, 9215-9217. [CrossRef]

4. Anderson, S.; Anderson, H.L. Synthesis of a water-soluble conjugated [3]rotaxane. Angew. Chem. Int. Ed. Engl. 1996, 35, 1956-1959. [CrossRef]

5. Zhang, C.; Chen, C.F. Synthesis and structure of a triptycene-based nanosized molecular cage. J. Org. Chem. 2007, 72, 9339-9341. [CrossRef] [PubMed]

6. Sienmsen, P.; Livingston, R.C.; Diederich, F. Acetylenic coupling: A powerful tool in molecular construction. Angew. Chem. Int. Ed. 2000, 39, 2632-2657. [CrossRef]

7. Sindhu, K.S.; Gopinathan, A. Recent advances and applications of Glaser coupling employing greener protocols. RSC Adv. 2014, 4, 27867-27887. [CrossRef]

8. Stefani, H.A.; Guarezemini, A.S.; Cella, R. Homocoupling reactions of alkynes, alkenes and alkyl compounds. Tetrahedron 2010, 66, 7871-7918. [CrossRef]

9. Alonso, F.; Yus, M. Heterogeneous catalytic homocoupling of terminal alkynes. ACS Catal. 2012, 2, $1441-1451$. [CrossRef]

10. Chinchilla, R.; Nájera, C. Chemical from alkynes with palladium catalysts. Chem. Rev. 2014, 114, 1783-1826. [CrossRef] [PubMed]

11. Li, J.H.; Liang, Y.; Zhang, X.D. Amine and phosphine-free palladium(II)-catalyzed homocoupling reaction of terminal alkynes. Tetrahedron 2005, 61, 1903-1907. [CrossRef]

12. Yang, F.; Cui, X.L.; Li, N.; Zhang, J.L.; Ren, G.R.; Wu, Y.J. Cyclopalladated ferrocenylimines: Efficient catalysts for homocoupling and Sonogashira reaction of terminal alkynes. Tetrahedron 2007, 63, 1963-1969. [CrossRef]

13. Chen, S.N.; Wu, W.Y.; Tsai, F.Y. Homocoupling reaction of terminal alkynes catalyzed by a reusable cationic 2,2'-bipyridyl palladium(II)/CuI system in water. Green Chem. 2009, 11, 269-274. [CrossRef]

14. Shi, M.; Qian, H.X. NHC-Pd(II) complex-Cu(I) cocatalyzed homocoupling reaction of terminal alkynes. Appl. Organomet. Chem. 2006, 20, 771-774. [CrossRef]

15. Li, J.H.; Liang, Y.; Xie, Y.X. Efficient palladium-catalyzed homocoupling reaction and sonogashira cross-coupling reaction of terminal alkynes under aerobic conditions. J. Org. Chem. 2005, 70, 4393-4396. [CrossRef] [PubMed] 
16. Gil-Moltó, J.; Nájera, C. Palladium(II) chloride and a (dipyridin-2-ylmethyl)amine-derived palladium(II) chloride complex as highly efficient catalysts for the synthesis of alkynes in water or in NMP and of diynes in the absence of reoxidant. Eur. J. Org. Chem. 2005, 19, 4073-4081. [CrossRef]

17. Wang, P.P.; Liu, X.Y.; Zhang, S.L. Ligand-free synthesis of 1,4-disubstituted-1,3-diynes by iron/copper cocatalyzed homocoupling of terminal alkynes. Chin. J. Chem. 2013, 31, 187-194. [CrossRef]

18. Wu, K.Y.; Guo, J.; Wang, C.C. Gelation of metalloporphyrin-based conjugated microporous polymers by oxidative homocoupling of terminal alkynes. Chem. Mater. 2014, 26, 6241-6250. [CrossRef]

19. Crowley, J.D.; Goldup, S.M.; Gowans, N.D.; Leigh, D.A.; Ronaldson, V.E.; Slawin, A.M.Z. An unusual nickel-copper-mediated alkyne homocoupling reaction for the active-template synthesis of [2]rotaxanes. J. Am. Chem. Soc. 2010, 132, 6243-6248. [CrossRef] [PubMed]

20. Krafft, M.E.; Hirosawa, C.; Dalal, N.; Ramsey, C.; Steigman, A. Cobalt-catalyzed homocoupling of terminal alkynes: Synthesis of 1,3-diynes. Tetrahedron Lett. 2001, 42, 7733-7736. [CrossRef]

21. Doménech, A.; Leyva-Pérez, A.; Al-Resayes, S.I.; Corma, A. Electrochemical monitoring of the oxidative coupling of alkynes catalyzed by triphenylphosphine gold complexes. Electrochem. Commun. 2012, 19, 145-148. [CrossRef]

22. Bharathi, P.; Periasamy, M. Direct Metalation of 1-alkynes using $\mathrm{TiCl}_{4} / \mathrm{Et}_{3} \mathrm{~N}$ and the reactions of the organotitanium intermediates with electrophiles. Organometallics 2000, 19, 5511-5513. [CrossRef]

23. Meng, X.; Li, C.; Han, B.; Wang, T.; Chen, B. Iron/copper promoted oxidative homo-coupling reaction of terminal alkynes using air as the oxidant. Tetrahedron 2010, 66, 4029-4031. [CrossRef]

24. Atobe, S.; Sonoda, M.; Suzuki, Y.; Yamamoto, T.; Masuno, H.; Shinohara, H.; Ogawa, A. Palladium-catalyzed oxidative homocoupling reaction of terminal acetylenes using tran-bidentatable 1-(2-pyridylethynyl)-2-(2-thienylethynyl)benzene. Res. Chem. Intermed. 2013, 39, 359-370. [CrossRef]

25. Chen, L.R.; Lemma, B.E.; Rich, J.S.; Mack, J. Freedom: A copper-free, oxidant-free and solvent-free palladium catalysed homocoupling reaction. Green Chem. 2014, 16, 1101-1103. [CrossRef]

26. Feng, X.J.; Zhao, Z.R.; Yang, F.; Jin, T.N.; Ma, Y.J.; Bao, M. 1,3-Diynes synthesis by homocoupling of terminal alkynes using a $\mathrm{Pd}\left(\mathrm{PPh}_{3}\right)_{4} / \mathrm{Ag}_{2} \mathrm{O}$ simple catalyst system. J. Organomet. Chem. 2011, 696, 1479-1482. [CrossRef]

27. Guo, M.P.; Zhang, Q. An inexpensive and highly stable palladium(II) complex for room temperature Suzuki coupling reactions under ambient atmosphere. Tetrahedron Lett. 2009, 50, 1965-1968. [CrossRef]

28. Guo, M.P.; Ge, J.Y.; Zhu, Z.Y.; Wu, X.C. Efficient Synthesis of aromatic nitriles via cyanation of aryl bromides and $\mathrm{K}_{4}\left[\mathrm{Fe}(\mathrm{CN})_{6}\right]$ catalyzed by a palladium(II) complex. Lett. Org. Chem. 2013, 10, 213-215. [CrossRef]

29. Yin, K.; Li, C.J.; Li, J.; Jia, X.S. CuI-catalyzed homocoupling of terminal alkynes to 1,3-diynes. Appl. Organomet. Chem. 2011, 25, 16-20. [CrossRef]

30. Wu, T.M.; Huang, S.H.; Tsai, F.Y. A reusable $\mathrm{CuSO}_{4} \cdot 5 \mathrm{H}_{2} \mathrm{O} /$ cationic 2,2'-bipyridyl system catalyzed homocoupling of terminal alkynes in water. Appl. Organomet. Chem. 2011, 25, 395-399. [CrossRef]

31. Shi, X.L.; Hu, Q.Q.; Wang, F.; Zhang, W.Q.; Duan, P.G. Application of the polyacrylonitrile fiber as a novel support for polymer-supported copper catalysts in terminal alkyne homocoupling reactions. J. Catal. 2016, 337, 233-239. [CrossRef]

32. Reddy, A.S.; Laali, K.K. Sonogashira cross-coupling in a designer ionic liquid (IL) without copper, external base, or additive, and with recycling and reuse of the IL. Tetrahedron Lett. 2015, 56, 4807-4810. [CrossRef]

33. Rao, M.L.N.; Dasgupta, P.; Ramakrishna, B.S.; Murty, V.N. Domino synthesis of 1,3-diynes from 1,1-dibromoalkenes: a Pd-catalyzed copper-free coupling method. Tetrahedron Lett. 2014, 55, 3529-3533. [CrossRef]

34. Zhang, W.S.; Xu, W.J.; Zhang, F.; Qu, G.R. Synthsis of symmetrical 1,3-diynes via tandem reaction of (Z)-arylvinyl bromides in the presence of DBU and CuI. Chinese Chem. Lett. 2013, 24, 407-410. [CrossRef]

Sample Availability: Samples of the compound (1) are available from the authors.

(C) 2016 by the authors; licensee MDPI, Basel, Switzerland. This article is an open access article distributed under the terms and conditions of the Creative Commons Attribution (CC-BY) license (http://creativecommons.org/licenses/by/4.0/). 